\title{
Design and simulation of stand-alone photovoltaic system supplying BTS in Iraq
}

\author{
Saja Mazin Sami, Anas Lateef Mahmood
}

Electronic and Communications Engineering Department, College of Engineering, Al-Nahrain University, Baghdad, Iraq

\begin{tabular}{l}
\hline \hline Article Info \\
\hline Article history: \\
Received Mar 21, 2020 \\
Revised Jan 15, 2021 \\
Accepted Feb 10, 2021
\end{tabular}

\section{Keywords:}

BTS

PV systems

Pvsyst6

Solar cells

Stand-alone

\begin{abstract}
The problem of power outages is still present in most cities of Iraq as a result of the wars and crises experienced by Iraq and this makes it difficult to provide continuous electric power to the electrical devices. All telecommunications companies, including Zain, Asia cell, etc in Iraq used diesel generators as an alternative source to the national electricity grid, but this will adversely affect the environment and humans as a result of toxic emissions associated with the use of these generators. In this paper, a standalone PVsystem was designed and simulated to supply a base transceiver station (BTS) in Iraq. A BTS in Jadriyah, Baghdad with $4.177 \mathrm{~kW}$ load power belong to Zain Telecommunication Company was taken as a case study in this paper. The meteorological data of the Jadriyah region were taken from a weather station belong to the ministry of Sciences and Technology in Iraq for the year 2017. The simulation for this BTS was carried out using the Pvsyst simulation program. The financial analysis of the proposed system shows that it has small kWh unit price $(0.108 \$ / \mathrm{kWh})$.
\end{abstract}

This is an open access article under the CC BY-SA license.

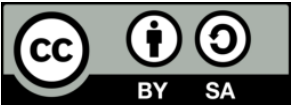

\section{Corresponding Author:}

Anas Lateef Mahmood

Electronic and Communications Department, College of Engineering

Al-Nahrain University, Jadriyah, Baghdad, Iraq

Email: anas.lateef.1@ced.nahrainuniv.edu.iq

\section{INTRODUCTION}

As a result of the growth of technologies in particular mobile communications systems many mobile communications companies are operating to coverage a great numeral of subscribers. Cellular network operator is required to build more telecommunication towers tocater to the increasing demand for transmission quality and extensive coverage [1]. However due to lack of stable grid power in rural or remote areas, telecom operators face a big challenge. So, telecom equipment is running on diesel generator (DG) or batteries during demand period which leads to a threat of global warming and $\mathrm{CO}_{2}$ emissions. This increases the focus on powering telecom towers through renewable energy sources like solar, wind, and tidal [2], [3]. So it was necessary to find another type of energy source and the Photovoltaic system is a good alternative source[4], especially in areas where the rate of radiation is high. Iraq is located in the northern hemisphere in Asia to the south of the Equator. The weather in the south and middle of Iraq is sunny almost of the year while it is less clear in the north. Middle and south regions of Iraq considered as one of the greatest solar radiation areas in the world [5]. The west region in Iraq has the highest solar irradiation among other regions with an average of $170 \mathrm{~W} / \mathrm{m}^{2}$; therefore it is the best region to use solar electricity obstetrics. In Baghdad, the yearly accumulative universal radiation is $(2160-7000) \mathrm{MJ} / \mathrm{m}^{2}[6]$. The largest solar radiation in Baghdad city is found in June and July and it is approximately equal to $\left(240 \mathrm{Wh} / \mathrm{m}^{2}\right)$ whilst the smallest solar radiation is found in December and it is approximately equal to $\left(80 \mathrm{Wh} / \mathrm{m}^{2}\right)$. Several studies like in [7] where AL-Riah, 
et al., resolve the medium monthly solar radiation in three major cities (Mosul in the north of Iraq, Baghdad in the middle of Iraq and Nasiriya in the south of Iraq) during the time 1971-1985. One of the biggest problems in Iraq through the bygone 40 years is the decay of the electrical network and the shortage of apparatus. Till 2017 the ministry of Electricity failed to provide electricity more than 12 hours a day in most cities in the country. Because of this long time of cut in the electric power made Iraqi peoples depend on diesel and petrol generators as an alternative solution to the electricity outage [8]. That reliance on generators brings about a large use of fuel of poor standard than bring about acute harm to the weather quality and the Iraqi climate. The Iraqi national has started to perceive the ecological danger connected to pollutants resulting in cars and generators [5]. Lessen fossil fuel consumption is the large defy that can be transferred on through Iraq to the utilization of renewable powers in electricity generation [5]. The best alternative power source that can be used instead of the diesel and petrol generators is that which depends on renewable energies and the main renewable energy appearing in Iraq is the solar energy [9]. Iraq has an extremely differentiate site close to the solar region countries allow the country to be given a tall volume of solar irradiation reach to $\left(7 \mathrm{kWh} / \mathrm{m}^{2}\right)$ with sunshine ranges of 2,800 to $3,300 \mathrm{~h} / \mathrm{y}$ [5]. The largest sunshine time found in June and it is about $11.4 \mathrm{~h} / \mathrm{d}$, while the shortest sunshine time found in January and it is about $6.3 \mathrm{~h} / \mathrm{d}$ [10]. BTS has to various indoor and outdoor both types supplied by $-48 \mathrm{~V}$ DC voltage. "Indoor mean refuge room which contains one or two aircondition unit and BTS electronics tools which work for subscribers" while "Outdoor mean the BTS electronics tools which work for subscribers are in one or more cabinet".

PV solar systems Consists of two Main units PV solar modules and batteries as back up at night, PV solar modules usable for 20-25 years [11]. Though PV system tall life span constructs the choice of PV Stand-alone system preferable; the small useable of storage battery growth the cost. Economically the better option is lead-acid (traditional) because of low cost and better execution at its life span [12]. There are many research efforts aimed at using solar energy to equip cellular stations [13]. Mohammed H. Alsharif and Jeong Kim they both study the feasibility of a solar system depends on the attributes of South Korean sunlight based radiation vitality required for a remote cellular base station, Homer software is used to decide the ideal size of the system parts, to work power produce analysis and to break down task cost subtleties [13]. Dike U. Ike, Anthony U. Adoghe, Ademola Abdulkareem, they have analyzed the importance of solar energy as a sustainable point of energy for BTS, the Pvsyst simulation program is used to calculate the cost of solar power generation, the simulation of solar energy systems has been achieved both on-grid and off-grid using the city of Benin, Nigeria [11]. Geetha Pande, Provide simulations utilize the Pvsyst software for on-grid and off-grid systems by looking at the status of New Delhi, India, Sweden and, Stockholm. Pvsyst simulation outcomes appear the cost of energy generation for the on-grid PV system is less comparative to off-grid in Stockholm, Sweden, and India, New Delhi [12].The sun-powered insolation local map of Iraq gives an idea about the average peak sun hours of Baghdad city. Sun oriented insolation map shows the amount of sunpowered energy of hours (peak hours of sun), be given throughout the day on an ideal incline surface through the more regrettable month from 12 months. The peak sun-powered hours outline is shown below in Figure 1 [14].

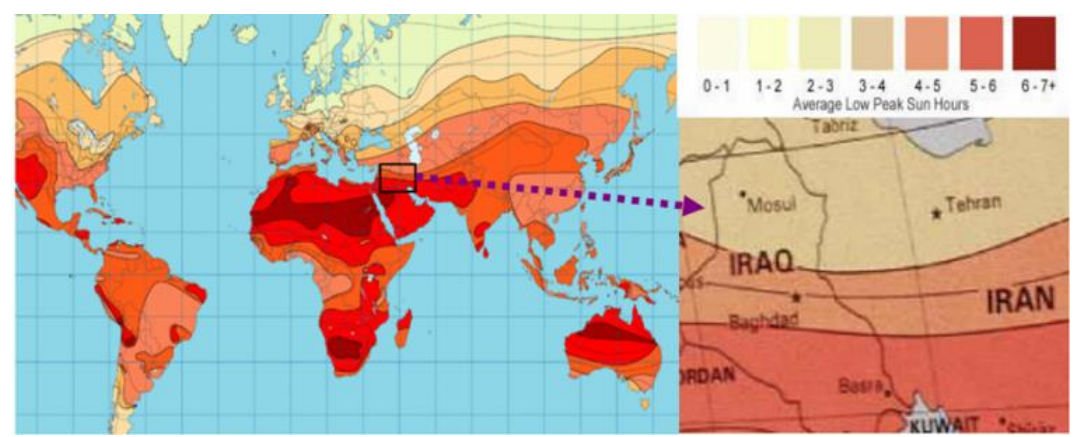

Figure 1. Iraq peak sun hour's solar power.

\section{STAND-ALONE SYSTEM FOR BTS}

This system contains from PV modules, DC-DC converter, batteries, charge controller and dc load (BTS) and it depends on converting the solar irradiation into electrical signals via PV cluster modules. During the day the PV modules supply the load through DC-DC converter and charge the batteries through the charge controller. In the night and overcast days, the batteries supply the load with the required power. The batteries' string size is vast to cover throughout the night and some shady days. Figure 2 shows the block 
diagram of the standalone system is a mix of solar PV exhibit modules which creates direct current (DC), controller and MPPT which control charging and releasing the batteries string and BTS load which including all dc loads. The first stage in the design should be to determine the full geographical coordinates of the Jadriyah area, Baghdad. The average monthly solar irradiation values in Jadriyah, Baghdad are shown in Table 1 and they were taken from weather stations belong to the Ministry of Sciences and Technology located in the same region for the year 2017 [15]. From these values, it is clear that the solar irradiations are very high, especially in the summer.

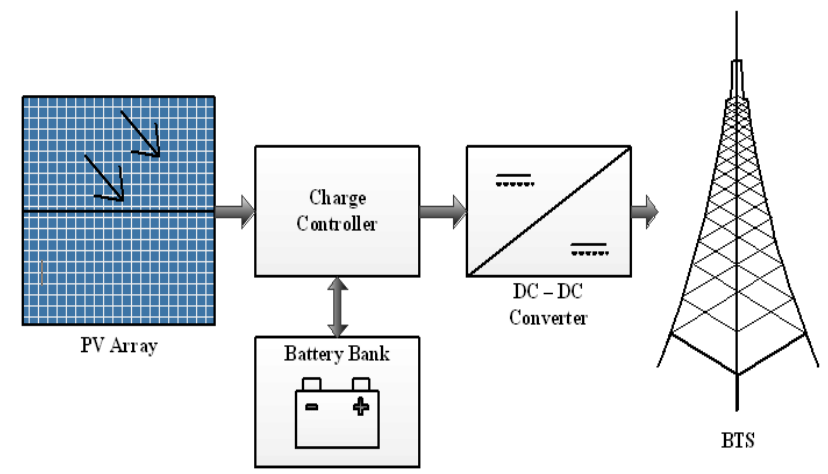

Figure 2. Stand-alone system for BTS block diagram

Table 1. Meteorological data of Jadriyah region

\begin{tabular}{cccc}
\hline Month & GHI $\left(\mathrm{kWh} / \mathrm{m}^{2}\right)$ & Wind speed $(\mathrm{m} / \mathrm{s})$ & Average air temp. ${ }^{\circ} \mathrm{C}$ \\
\hline January & 78 & 2.45 & 10.4 \\
February & 107.6 & 2.55 & 11.4 \\
March & 136.9 & 2.63 & 18 \\
April & 162.4 & 2.94 & 23.6 \\
May & 200.6 & 2.97 & 31.2 \\
June & 229.7 & 3.58 & 35.5 \\
July & 222.8 & 3.63 & 39.8 \\
August & 199.1 & 3.46 & 39.5 \\
September & 141.8 & 2.74 & 35.8 \\
October & 103.6 & 2.38 & 27.3 \\
November & 73.09 & 2.33 & 19.7 \\
December & 76.9 & 2.53 & 14.6 \\
\hline
\end{tabular}

GHI/Global horizontal irradiance

\section{ELECTRICAL DEMAND}

The off-grid PV system is planned to supply electrical energy to the BTS (DC load)in the Jadiriah, Iraq. BTS requires $4.177 \mathrm{~kW}$ energy to work its loads. Table 2 shows the required power and the time of operation for BTS in the Jadriyah region belong to Zain Telecommunication Company.

Table 2. Electrical load for Jadriyah telecom tower site

\begin{tabular}{ccccc}
\hline Appliance & Power $(\mathrm{W})$ & Qty. & Working time $(\mathrm{h})$ & Energy consumption (Wh/day) \\
\hline Microwave & 500 & 1 & 24 & 12000 \\
RF radio & 315 & 3 & 24 & 226680 \\
RF radio & 444 & 3 & 24 & 31968 \\
Base band & 200 & 1 & 24 & 4800 \\
Fan unit & 180 & 1 & 24 & 4320 \\
RF radio & 340 & 3 & 24 & 24480 \\
Total daily demand $=100248 \mathrm{~kW} /$ day & &
\end{tabular}

Figure 3 shows the geographical location of the Jadriyah area in Iraq using the Google Earth program. It is a neighborhood inBaghdad,Iraqalong theTigris River. It lies at the south tip of the peninsula where Tigris River makes its major turn and heads to the north-east. Because of the fact that Iraq is in the northern hemisphere, the best mode for directing solar cell panels is to the south because the solar cells will be facing the path of the sun and thus it will be possible to obtain the highest solar radiation in order to obtain 
the best power production of the panel [16]. Table 3 shows the yearly solar radiation with different tilt angles for Baghdad city [16].

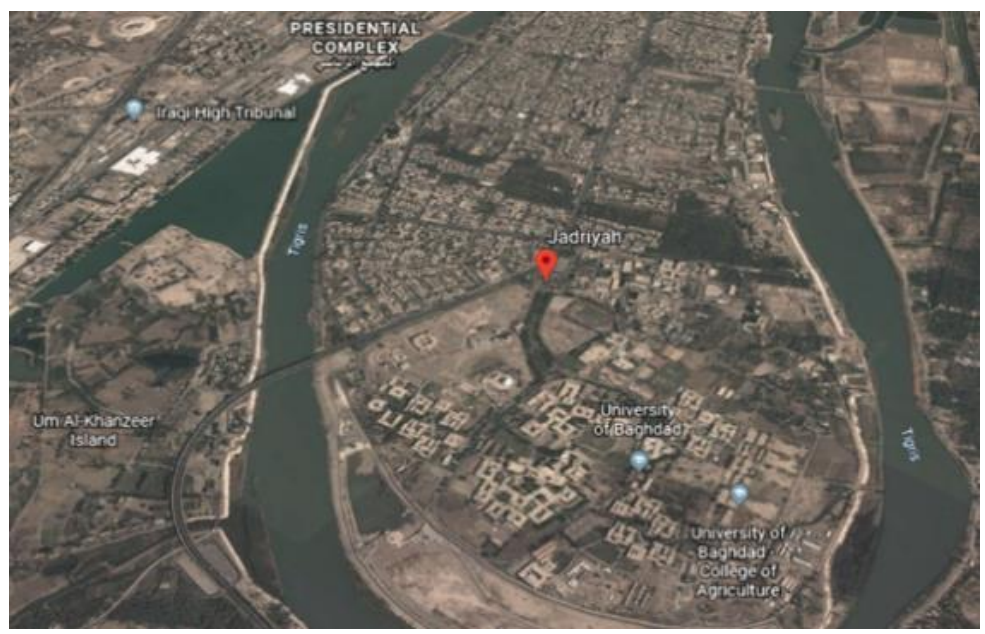

Figure 3. The geographical location of the Jadriyah area in Iraq

Table 3. Yearly solar radiation with different tilt angles.

\begin{tabular}{cc}
\hline Tilt angle & Yearly mean radiation $\left(\mathrm{kW} / \mathrm{m}^{2} /\right.$ day $)$ \\
\hline $0^{\circ}$ & 5.3 \\
$10^{\circ}$ & 5.7 \\
$20^{\circ}$ & 6 \\
$30^{\circ}$ & 6.08 \\
$35^{\circ}$ & 6.04 \\
$40^{\circ}$ & 5.9 \\
$50^{\circ}$ & 5.6 \\
$60^{\circ}$ & 5.1 \\
$90^{\circ}$ & 2.8 \\
\hline
\end{tabular}

\section{PV SYSTEM DESIGN}

The off-grid PV system generally consists of the PV array with the in-demand mechanistic construction, storage batteries, charge controller, cables and switching devices. The next subsections explain the design of all constituent in the suggested system.

\subsection{PV sizing}

The solar panel includes a group of PV cells linked in series and parallel, the electrical power generated by this panel is inadequate to deal with average and big loads of energy. In order to obtain the required load voltage, a group of PV panels must be connected in series whilst to obtain the required load current PV panels are linked in parallel. However, prior beginning to account the number of series and parallel solar cell panels the next information must be known:

(Vdc) The dc system voltage.

(Tsh) The mean sun $\mathrm{h} / \mathrm{d}$.

(Ed) The mean daily demand for energy in wh.

In the first step in an account, the number of solar panels starts by knowing the average daily demand of energy (Erd) that is found by dividing the mean daily demand over the product of system component efficiencies as shown in (1) [5].

$$
\mathrm{E}_{\mathrm{rd}}=\frac{\mathrm{Ed}}{n \mathrm{~b} n \operatorname{con} n c}
$$

where:

$$
\begin{array}{ll}
n \mathrm{~b} & =\text { Efficiency of battery } \\
n \mathrm{con} & =\text { Efficiency of converter } \\
n c & =\text { Efficiency of charge controller }
\end{array}
$$


The second step is to calculate the average peak power (Pave,peak) by dividing the average energy demand required by the mean sun hours for the site during the day as (2):

$$
\mathrm{P}_{\text {ave peak }}=\frac{\text { Erd }}{\text { Tsh }}
$$

System dc current can be calculated depends on the values of the average peak power and the dc system voltage as (3):

$$
\mathrm{I}_{\mathrm{dc}}=\frac{\mathrm{P}_{\mathrm{ave}, \mathrm{peak}}}{\mathrm{V}_{\mathrm{dc}}}
$$

Next, the number of models in series $\left(\mathrm{N}_{\mathrm{sm}}\right)$ is calculated by dividing the system dc voltage by the rated voltage per model $\left(\mathrm{V}_{\mathrm{rm}}\right)$ as shown in (4):

$$
\mathrm{N}_{\mathrm{sm}}=\frac{\mathrm{v}_{\mathrm{dc}}}{\mathrm{V}_{\mathrm{rm}}}
$$

The parallel number of module strings $\left(\mathrm{N}_{\mathrm{pm}}\right)$ can be calculated by dividing the dc system current by the rated current of each module $\left(\mathrm{I}_{\mathrm{rm}}\right)$ as shown below:

$$
\mathrm{N}_{\mathrm{pm}}=\frac{\mathrm{I}_{\mathrm{dc}}}{\mathrm{I}_{\mathrm{rm}}}
$$

Finally, the total number of modules $\left(\mathrm{N}_{\mathrm{tm}}\right)$ can be calculated by multiplying the number of modules in series by the number of parallel modules:

$$
\mathrm{N}_{\mathrm{tm}}=\mathrm{N}_{\mathrm{sm}} \times \mathrm{N}_{\mathrm{pm}}
$$

Table 4 shows the PV array sizing step outline for the case study in this paper.

Table 4. PV array sizing.

\begin{tabular}{cc}
\hline Solar module: CSUN Solar, CSUN 310-72P, $310 \mathrm{~W}, \mathrm{Vrm}=\mathrm{Vmp}=31 \mathrm{~V}, \operatorname{Irm}=\operatorname{Imp}=8.4 \mathrm{~A}, \mathrm{I}_{\mathrm{sc}}^{\mathrm{m}}=8.94 \mathrm{~A}$. \\
Voltage of dc system $(\mathrm{Vdc})=48 \mathrm{~V}$. Mean sun-hours for Baghdad $(\mathrm{Tsh})=6$, Efficiency of battery $(\eta \mathrm{b})=$ \\
0.97. Efficiency of converter $(\eta \operatorname{con})=0.96$. Charge Controller Efficiency $(\eta \mathrm{c})=0.95$, Daily average \\
demand $(\mathrm{Ed})=100248 \mathrm{Wh}$. \\
\hline Variable being specified & Calculated value \\
\hline $\mathrm{E}_{\mathrm{rd}}$ & 113320.67 \\
$\mathrm{P}_{\mathrm{avepeak}}$ & 18886.8 \\
$\mathrm{I}_{\mathrm{dc}}$ & 393.5 \\
$\mathrm{~N}_{\mathrm{sm}}$ & 2 \\
$\mathrm{~N}_{\mathrm{pm}}$ & 47 \\
$\mathrm{~N}_{\mathrm{tm}}$ & 94 \\
\hline
\end{tabular}

\subsection{Battery bank sizing}

To determine the size of the desired batteries, it is necessary to know the estimated storage capacity required $\left(E_{\text {est }}\right)$, which represents the average daily energy demand times the number of autonomy days $\left(D_{\text {aut }}\right)$ as shown in (7) [5].

$$
\mathrm{E}_{\text {est }}=\mathrm{E}_{\mathrm{rd}} \times \mathrm{D}_{\text {aut }}
$$

The safe storage of energy is thereafter found via dividing the $\left(\mathrm{E}_{\mathrm{safe}}\right)$ by the depth of discharge $\left(\mathrm{D}_{\text {disch }}\right)$ as (8):

$$
\mathrm{E}_{\text {safe }}=\frac{\mathrm{E}_{\mathrm{est}}}{\mathrm{D}_{\mathrm{disch}}}
$$

The total capacity of the battery bank $\left(\mathrm{C}_{\mathrm{tb}}\right)$ is found by dividing $\left(\mathrm{E}_{\mathrm{safe}}\right)$ over the single battery dc voltage $\left(\mathrm{V}_{\mathrm{b}}\right)$ as shown in $(9)$.

$$
\mathrm{C}_{\mathrm{tb}}=\frac{\mathrm{E}_{\mathrm{safe}}}{\mathrm{V}_{\mathrm{b}}}
$$



$\left(\mathrm{C}_{\mathrm{b}}\right)$ as $(10)$ :

$\left(\mathrm{N}_{\mathrm{tb}}\right)$ the total number of batteries can be found by dividing the $\left(\mathrm{C}_{\mathrm{tb}}\right)$ over the capacity of one battery

$$
\mathrm{N}_{\mathrm{tb}}=\frac{\mathrm{C}_{\mathrm{tb}}}{\mathrm{C}_{\mathrm{b}}}
$$

The number of batteries in series $\left(\mathrm{N}_{\mathrm{sb}}\right)$ can be specified by dividing the system dc voltage $\left(\mathrm{V}_{\mathrm{dc}}\right)$ by the dc voltage of one battery as (11):

$$
\mathrm{N}_{\mathrm{sb}}=\frac{\mathrm{v}_{\mathrm{dc}}}{\mathrm{v}_{\mathrm{b}}}
$$

The number of parallel battery strings $\left(\mathrm{N}_{\mathrm{pb}}\right)$ can be specified by dividing the total number of batteries over the number of series batteries as (12):

$$
\mathrm{N}_{\mathrm{pb}}=\frac{\mathrm{N}_{\mathrm{tb}}}{\mathrm{N}_{\mathrm{sb}}}
$$

\begin{tabular}{|c|c|}
\hline \multicolumn{2}{|c|}{$\begin{array}{l}\text { Battery module: Narada, AcmeG } 12 \mathrm{~V} 200, \mathrm{Cb}=200 \mathrm{Ah}, \mathrm{Vb}=12 \mathrm{~V}, \mathrm{Ddisch}=80 \% \\
\text { Efficiency of battery }(\eta \mathrm{b})=0.97 \text {. Number of Days of Autonomy (Daut) }=2.5 \text { Days }\end{array}$} \\
\hline Variable being specified & Calculated value \\
\hline $\mathrm{E}_{\text {est }}$ & 250620 \\
\hline$E_{\text {safe }}$ & 313275 \\
\hline $\mathrm{C}_{\mathrm{tb}}$ & 26106.25 \\
\hline $\mathrm{N}_{\mathrm{sb}}$ & 4 \\
\hline $\mathrm{N}_{\mathrm{tb}}$ & 132 \\
\hline$N_{p b}$ & 33 \\
\hline
\end{tabular}

Table 5 shows the battery bank sizing step outline for the case study in this paper.

Table 5. Battery bank sizing

\subsection{Charge controller sizing}

The major task of the solar charge controller unit is to dominance the current amount of the solar cells moreover the total current amount of the load with make sure that the voltages of the solar cells and load voltage are the same. The maximum significant point in definition the capacity of the solar charge controller unit is its capacity to bearing the total short circuit current of the array $\left(\mathrm{I}_{\mathrm{sc}}^{\mathrm{A}}=\mathrm{I}_{\mathrm{sc}}^{\mathrm{m}} \times \mathrm{N}_{\mathrm{pm}}\right)$ and a certain safe factor $\left(\mathrm{F}_{\text {safe }}\right)$. The $\left(\mathrm{F}_{\text {safe }}\right)$ is needful for permitting for a sensible system growth. Therefore, the required charge controller current $\left(\mathrm{I}_{\mathrm{cc}}\right)$ is shown in (13):

$\mathrm{I}_{\mathrm{CC}}=\mathrm{I}_{\mathrm{sc}}^{\mathrm{m}} \times \mathrm{N}_{\mathrm{pm}} \times \mathrm{F}_{\text {safe }}$

$\mathrm{I}_{\mathrm{Sc}}^{\mathrm{m}}=$ The short circuit current of the chosen module

Table 6 shows the charge controller sizing for the case study in this paper.

Table 6. Charge controller sizing

\begin{tabular}{cc}
\hline Charge controller: VarioTrack VT80 - 48V, Studer with MPPT converter, $48 \mathrm{~V}$ \\
$\mathrm{I}_{\mathrm{sc}}^{\mathrm{m}}=8.94 \mathrm{~A}$, Charge Controller Efficiency $(\eta \mathrm{c})=0.95$. Safety factor (Fsafe) $=1.25[17]$ \\
\hline Variable being specified & Calculated value \\
\hline $\mathrm{I}_{\mathrm{ccr}}$ & $525.225 \mathrm{~A}$ \\
Number of controllers & 5 \\
\hline
\end{tabular}

\section{SIMULATION USING PVSYST6.80 (PHOTOVOLTAIC SYSTEM SOFTWARE)}

By using simulation tools, at variance to sizing apparatus, the user should state the kind and size of all components. The tools thereafter supply a comprehensive analysis of the conduct of the system. In that action for the modeling, analysis, and simulation, Pvsyst6.8 software is applied. The Pvsysts6.8 software pick load required and solar power data and; models PV, controller and MPPT converter and batteries with various sizes to correspond the request. The system designed in this study for the BTS of the Jadriyah area of Iraq consists of a PV system as an energy source. Pvsyst coordinates pre-practicality, measuring and 
reenactment support for the PV system. In the wake of having characterized the area and load, the user chooses the various constituent from an item database and the software consequently computes the measure of every constituent.The geographical position of the PV framework utilizing Google earth for the Jadriyah area, Baghdad, Iraq shown in Table 7.Meteorological data were obtained from stations of the Iraqi Ministry of Science and Technology. In the Albedo-Settings tab, the Albedo esteems are set to 0.2 for the solid surface. The particular parameters of the tilt and azimuth edges of the framework are given in Table 8 .

By using simulation tools, at variance to sizing apparatus, the user should stat the kind and size of all components. The tools thereafter supply a comprehensive analysis of the conduct of the system. In that action for the modeling, analysis and simulation, Pvsyst6.8. Software is applied. The Pvsyst6.8 software pick load required and solar power data and; models PV, controller and MPPT converter and batteries with various sizes to correspond the request. The system designed in this study for the BTS of the Jadriyah area of Iraq consists of a PV system as an energy source. Pvsyst coordinates pre-practicality, measuring and reenactment support for the PV system. In the wake of having characterized the area and load, the user chooses the various constituent from an item database and the software consequently computes the measure of every constituent. Meteorological data were obtained from the Ministry of Science and Technology databases containing meteorological stations in the Jadriyah, Baghdad. At the Albedo-tuning tag the Albedo esteems are chosen 0.2 for solid surface. The chosen variables into azimuth and tilt angles are shown in Figure 4.

South is $0^{\circ}$ as indicated by Figure 4 . The PV modules chosse for this investigation is a CSUN Solar. (CSUN 310-72P, 310Wp, 31V Si-poly [18], while the battery set chosse is Narada, AcmeG 12V 200, 12V, 200Ah [19]. The sunlight based way skyline at Baghdad city is appeared in Figures 5,6 and 7 show the simulated daily input /output diagram\& (per installed $\mathrm{kWp}$ ).

Table 7. The geographical position of the

\begin{tabular}{crcr}
\multicolumn{4}{c}{ PV system } \\
\hline Latitude & 33.2 & Altitude & 34 \\
\hline Longitude & 44.3 & Time zone & 3 \\
\hline
\end{tabular}

Tilt $33^{\circ}$

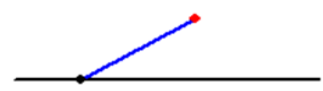

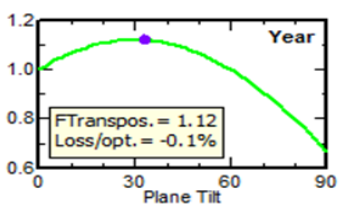
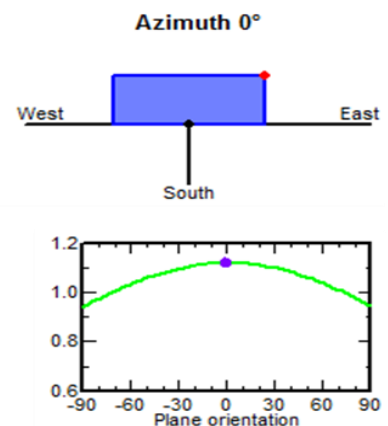

Figure 4. Tilt and azimuth angle selection in Pvsyst6

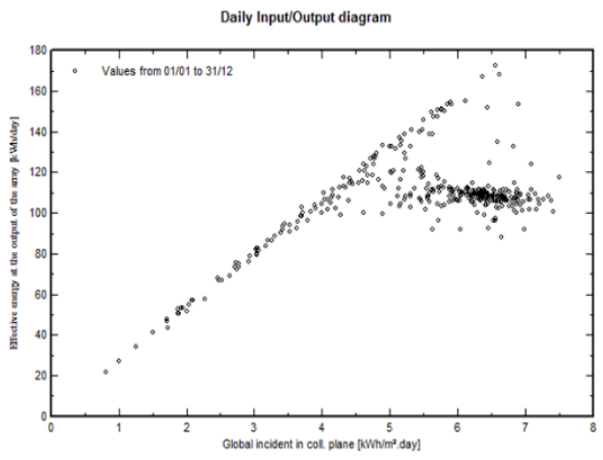

Figure 6. The daily generated power
Table 8. Orientation parameters selected in Pvsyst

\begin{tabular}{cc}
\hline Tilt angle & $33^{\circ}$ \\
\hline Azimuth angle & $0^{\circ}$ \\
Field type & Fixed \\
\hline
\end{tabular}

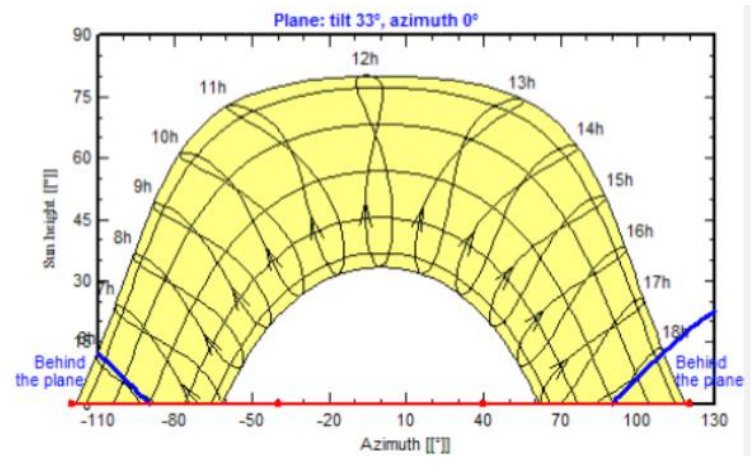

Figure 5. The sunlight based way skyline at Baghdad city

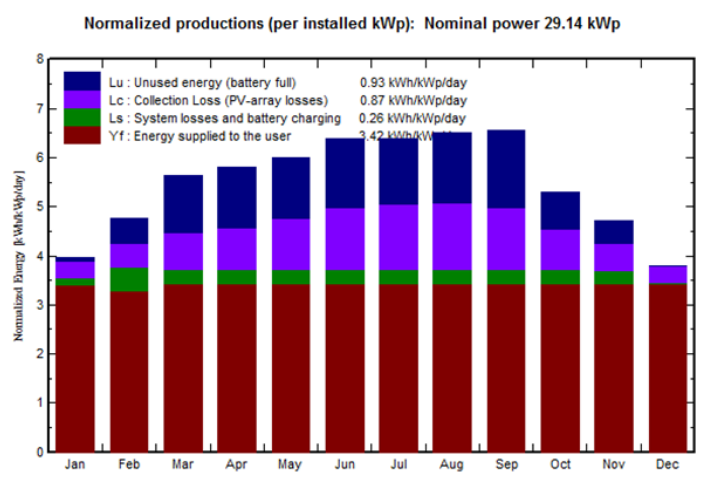

Figure 7. The normalized production energy in the site 
A similar work is done by Dr.Kareem, et al., [20] where they designed Hybrid PV/Diesel Power System for Algazalia telecom tower site with $32.25 \mathrm{kWh}$ /day energy consumption; the final design contains $63 \mathrm{PV}$ panels $(3 \times 21)\left(\right.$ Kyocera-135W) with $63 \mathrm{~m}^{2}$ area in addition to two $5.5 \mathrm{~kW}$ diesel generators each one work for 12 hours per day. The number of batteries in their design was 24 batteries in series, (each battery rated at $2 \mathrm{~V} / 2500 \mathrm{Ah}$ ).

However, figure 8 demonstrates the simulation results from the last report given by the Pvsyst6.8 simulation program.

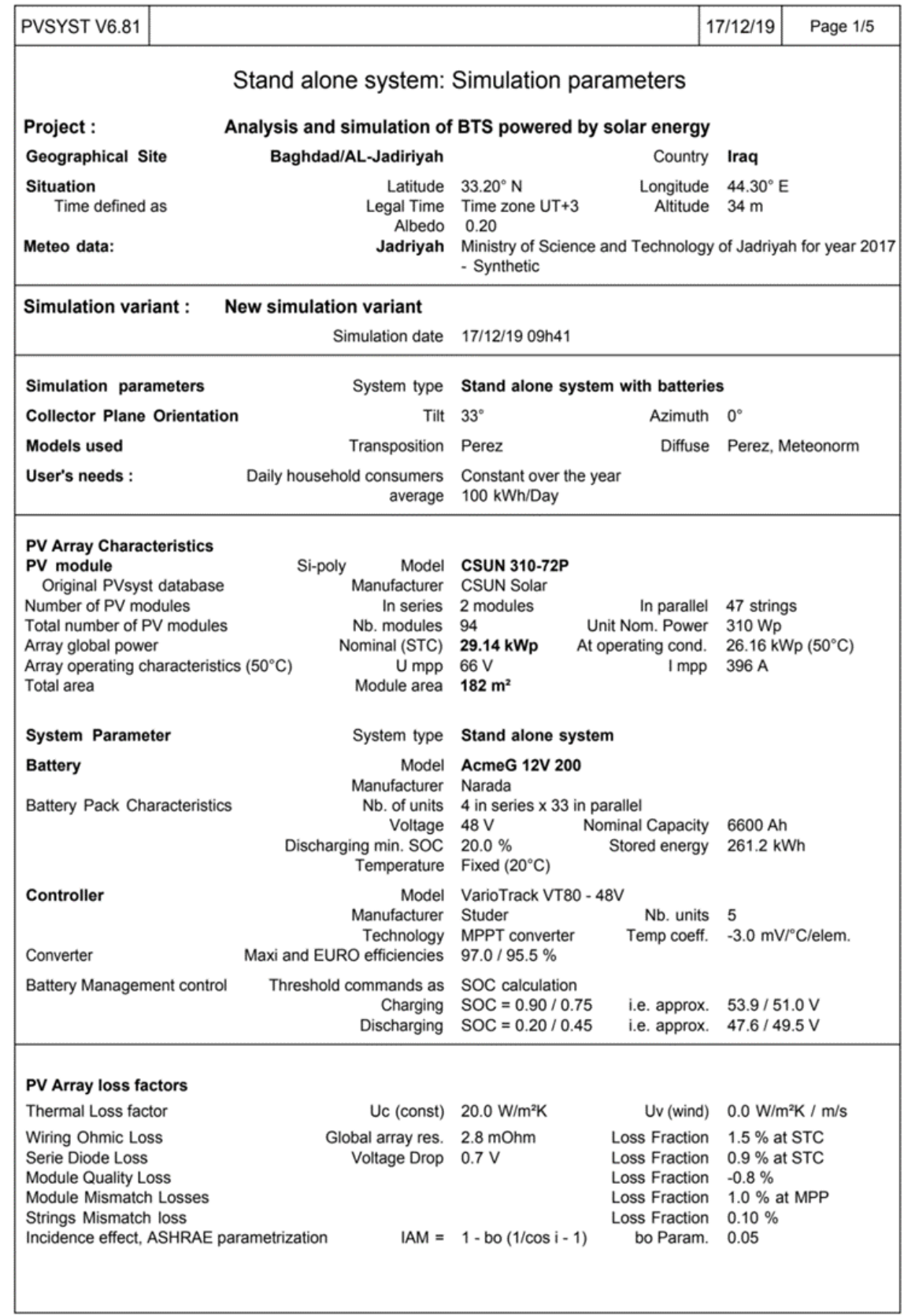

Figure 8. Simulation results for the proposed PV system

\section{FINANCIAL ANALYSIS}

The most significant measurable assessment device for the monetary conduct of vitality frameworks is the cost of cycle life $\left(\mathrm{LC}_{\mathrm{C}}\right)$ investigation. The underlying capital expense of at all system is the demand cost for buying all system parts; this incorporates PV clusters, stockpiling system, charge of controller, 
establishment (counting wiring and different helpers). Operating and maintenance costs $\left(\mathrm{OM}_{\mathrm{C}}\right)$ incorporate yearly intermittent costs for the system the board, ordinary support and site administration. For nonstop activity and to guarantee proficient system execution, a few pieces of the system must be supplanted occasionally. In the life cycle examination, the examination must be completed by the longest part of the lifetime of all parts of the system. The ideal life cycle of the photovoltaic modules used is about 25 years, while the cycle of battery life can last up to 12 years. Due to the maximum life cycle of 25 years, batteries must be replaced every 12 years. For future estimations, two significant parameters must be considered; the inflation rate and the rebate rate. The inflation rate speaks to the acceleration pattern in the expenses overall system life, while the markdown rate speaks to the reduction in the segments cost with future large scale manufacturing. The cost of the selected PV module $\left(\mathrm{PV}_{\mathrm{C}}\right)$ is $\$ 62$, while the cost of the battery $\left(\mathrm{B}_{\mathrm{C}}\right)$ is $\$ 200$. Charge controller $\left(\mathrm{C}_{\mathrm{C}}\right)$ costs $\$ 633$. For the PV clusters life cycle of 25 years and the 12 years battery life, the establishment cost $\left(\mathrm{I}_{\mathrm{C}}\right)$ is $10 \%$ of the PV cost while the yearly $\left(\mathrm{OM}_{\mathrm{C}}\right)$ cost is $2 \%$ of the PV beginning expense [21]. Specified an inflation rate (i) of $4 \%$ and rebate rate (d) of $8 \%$, the system life cycle cost and the unit electrical expense can be evaluated. The yearly $\left(\mathrm{OM}_{\mathrm{C}}\right)$ expenses can be determined to rely upon the system capital cost thinking about the inflation and markdown rates as (14) [21].

$$
\mathrm{OM}_{\mathrm{C}}=2 \% \mathrm{PV}_{\mathrm{C}} \times\left(\frac{1+i}{1+d}\right)\left[\frac{\left(1-\frac{1+i}{1+d}\right)^{25}}{1-\left(\frac{1+i}{1+d}\right)}\right]
$$

Because the battery life is 12 years, it is replaced twice in the lifetime of the system. The first time battery replacement costs are calculated after 12 years and after 24 years are replaced again as shown in the (15) and (16) [22];

$$
\begin{aligned}
& \mathrm{B}_{\mathrm{c} 1}=\mathrm{B}_{\mathrm{c}}\left[\frac{1+i}{1+d}\right]^{12} \\
& \mathrm{~B}_{\mathrm{c} 2}=\mathrm{B}_{\mathrm{c}}\left[\frac{1+i}{1+d}\right]^{24}
\end{aligned}
$$

The cost of the system's cycle of life can be determined by including the PV module, batteries, battery substitutions, controller of charge, establishment, activity and support costs [23].

$$
\mathrm{LC}_{\mathrm{c}}=\mathrm{PV}_{\mathrm{c}}+\mathrm{B}_{\mathrm{c}}+\mathrm{B}_{\mathrm{c} 1}+\mathrm{B}_{\mathrm{c} 2}+\mathrm{C}_{\mathrm{c}}+\mathrm{I}_{\mathrm{c}}+\mathrm{OM}_{\mathrm{c}}
$$

The yearly cost of the life cycle $\left(\mathrm{ALC}_{\mathrm{C}}\right)$ can be evaluated as $(18)$;

$$
\mathrm{ALC}_{\mathrm{c}}=\operatorname{LC}_{\mathrm{c}}\left[\frac{1-\left(\frac{1+i}{1+d}\right)}{1-\left(\frac{1+i}{1+d}\right)^{25}}\right]
$$

The unit electrical expense $\left(\mathrm{U}_{\mathrm{C}}\right)$ in $\$ / \mathrm{kWh}$ can be evaluated from the yearly cost of life cycle and the yearly power produced by the PV system (19) [24].

$$
\mathrm{U}_{\mathrm{c}}=\frac{\mathrm{ALC}_{\mathrm{C}}}{365 \times \mathrm{EL}}
$$

EL is the daily demand electrical power for the family, $\mathrm{kWh} /$ day. As indicated by the above approach, Table 9 condenses the cost examination of the PV system, the expenses of Cables, Design, Metering, and Control devices are lighted together as $10 \%$ of tools cost.

Table 9. Estimated cost of the PV system parts.

\begin{tabular}{cccc}
\hline Component & Qty. & Unit cost & Total cost \\
\hline PV module & 94 & $\$ 62$ & $\$ 5828$ \\
Battery & 132 & $\$ 200$ & $\$ 26400$ \\
Controller & 5 & $\$ 633$ & $\$ 3165$ \\
Cables & Lot. & & $\$ 583$ \\
$1^{\text {st }}$ batteries replacement & & & $\$ 16785$ \\
$2^{\text {nd }}$ batteries replacement & & & $\$ 10672$ \\
OM $_{C}$ & & & $\$ 1851.7$ \\
LC $_{C}$ & & & $\$ 65284.7$ \\
ALC $_{C}$ & & & $0.10815 \$ / \mathrm{kWh}$ \\
$\mathrm{U}_{\mathrm{C}}$ & & \\
\hline
\end{tabular}




\section{CONCLUSION}

In this paper, $29.14 \mathrm{kWp}$ off-grid PV systems were proposed to outfit BTS in the Jadriyah area, Iraq to outfit the loads through the work time. The design of the PV system was simulated using the Pvsyst simulation pack utilizing the information got from the Ministry of Science and Technology databases for Baghdad. The results showed that an independent photoelectric system can be a good alternative energy system for providing power to the main transmitting and receiving stations of a mobile communication system. Critical analysis shows that the energy used costs $0.1081527 \$ / \mathrm{kWh}$ and is small compared to an alternative source such as diesel generators, as the energy used by a diesel generator for the same load costs $0.3641 \$ / \mathrm{kWh}$ calculated using the site https://power-calculation.com. Pvsyst simulation shows that the proposed photoelectric system has saved 990,534 tons of carbon dioxide emissions for 25 years.

\section{REFERENCES}

[1] A. Abdulmula, KamaruzzamanSopian, Lim Chin Haw, Ahmad Fazlizan, "Performance evaluation of standalone double axis solar tracking system with maximum light detection MLD for telecommunication towers in Malaysia," International Journal of Power Electronics and Drive System (IJPEDS), vol. 10, no. 1, pp. 444-453, 2019.

[2] W. Margaret Amutha, H. Caleb Andrew, A. DebieShajie, J. Praveen Immanuel Paulraj, "Renewable power interface based rural telecom," International Journal of Power Electronics and Drive System (IJPEDS), vol. 10, no. 2, pp. 917-927, 2019.

[3] K. Hossam, A. R. Mikhail, I. M. Hafez, and W. R. Anis, "Optimum Design of PV Systems for BTS in Remote and Urban Areas," International Journal of Scientific \& Technology Research, vol. 5, no. 6, pp. 355-363, 2016.

[4] Ahmad Fudholi, Lim Chin Haw, KamaruzzamanSopian, Ahmed Mohamed Omer Abdulmula, "A Primary Study of Tracking Photovoltaic System for Mobile Station in Malaysia,"International Journal of Power Electronics and Drive System (IJPEDS), vol. 9, no. 1, pp. 427-432, 2018.

[5] A. L. Mahmood, "Design and Simulation of Stand-alone PV System for Electronic and Communications Engineering Department Laboratories in Al-Nahrain University," European Union Digital Library (EUDL), vol. 19, no. 22, 2019.

[6] F. M. Abed, Y. Al-Douri, and G. M. Y. Al-Shahery, "Review on the energy and renewable energy status in Iraq: The outlooks," Renewable and Sustainable Energy Reviews, vol. 39, pp. 816-827, 2014.

[7] M. Al-Riahi, N. Al-Hamdani, and H. Al-Saffar, "Some aspects of solar radiation climatology of Iraq," Renewable and Sustainable Energy Reviews, vol. 2, no. 2, pp. 167-173, 1992.

[8] H. A. Kazem and M. T. Chaichan, "Status and future prospects of renewable energy in Iraq," Renewable and Sustainable Energy Reviews, vol. 16, no. 8, pp. 6007-6012, 2012.

[9] Z. Abdmouleh, R. A. M. Alammari, and A. Gastli, "Recommendations on renewable energy policies for the GCC countries," Renewable and Sustainable Energy Reviews, vol. 50, pp. 1181-1191, 2015.

[10] K. I. Abass, "Is Iraq Ready to Use Solar Energy Applications: A Review Khaleel Ibrahim Abass," International Journal of Engineering Science Invention, vol. 6, no. 10, pp. 27-42, 2017.

[11] D. U. Ike, A. U. Adoghe, and A. Abdulkareem, "Analysis of Telecom Base Stations Powered by Solar Energy," international journal of scientific \& technology research, vol. 3, no. 4, pp. 369-374, 2014.

[12] GeethaPande,"A Case Study of Solar Powered Cellular Base Stations," Master's Thesis in Energy Systems, University of Gavle, 2009.

[13] M. H. Alsharif and J. Kim, "Optimal solar power system for remote telecommunication base stations: A case study based on the characteristics of South Korea's solar radiation exposure," Sustainability, vol. 8, no. 9, pp. 942-963, 2016.

[14] Curtis Austin, Ralph Borja, and Jeffery Phillips, "A Study Examining Photovoltaic (PV) Solar Power as an Alternative for the Rebuilding of the Iraqi Electrical Power Generation Infrastructure," MBA professional report, NAVAL postgraduate school, 2005.

[15] AnasLateefMahmood, Amina Mahmoud Shakir, BahaaAbdulkhaliqNuman, "Design and performance analysis of stand-alone PV system at Al-Nahrain University, Baghdad, Iraq,"International Journal of Power Electronics and Drive System (IJPEDS), vol. 11, no. 2, pp. 921-930, 2020.

[16] Emad Jaleel Mahdi, Sahib Nama Abdul-Wahid, Sarmad Shaker Abdulstar, Sabiha A. Sahab, and Asmaa Hassan Mosli, "Optimum Orientation of Solar Panels in Baghdad city," Journal of Basrah Researches ((Sciences)), vol. 37, no. 3, pp. 1-9, 2011.

[17] Shaimaa R. Spea, and Heba A. Khattab, "Design, Sizing and Performance Analysis of Stand-Alone PV System using PVsyst Software for a location in Egypt,"2019 21st International Middle East Power Systems Conference (MEPCON), Cairo, Egypt, 2019, pp. 927-932.

[18] "Campus Map," 2013. [Online]. Available: http://www.csun.com.tr/uploaded/files/CSUN-\%20Catalogue$\% 20$ ENG.pdf

[19] Narada, "stored Energy Solutions for a Demanding Wolrld," 2012. [Online]. Available: http://en.naradapower.com/upload/at/file/20160616/1466059468118763p4ED.pdf

[20] Dr. Kareem K. Jasim, Dr. Mahdi A. Abdul-Hussain, "Optimization of Hybrid PV/Diesel Power Systemfor Remote Telecom Station," International Journal of Application or Innovation in Engineering \& Management (IJAIEM), vol. 5, no. 3, pp. 39-46, 2016.

[21] P. O. Otasowie and P. I. Ezomo, "Life Cycle Cost Analysis for the Economic Viability for Solar and National Grid for Powering BTS," Journal of Energy Technologies and Policy, vol. 5, no. 3, pp. 49-55, 2015. 
[22] A. Ghafoor and A. Munir, "Design and economics analysis of an off-grid PV system for household electrification," Renewable and Sustainable Energy Reviews, vol. 42, pp. 496-502, 2015.

[23] E. T. El Shenawy, A. H. Hegazy and M. abdellatef, "Design and Optimization of Stand-lone PV System for Egyptian Rural Communities," International Journal of Applied Engineering Research, vol. 12, no. 20, pp. 10433-10446, 2017.

[24] Solomon DerbieGont, "Design of a Standalone Photovoltaic System for a Typical Household around Dessie CityEthiopia," American Journal of Electrical and Electronic Engineering, vol. 7, no. 1, pp. 1-7, 2019.

[25] "Power Calculation," 2015. [Online]. Available: https://power-calculation.com/electrical-power-current-calculator3-single-phase.php

\section{BIOGRAPHIES OF AUTHORS}

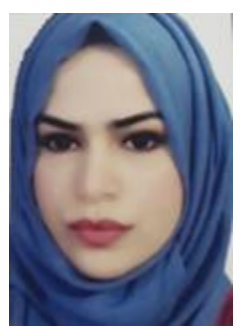

Saja Mazin Sami received her B.Sc. degree in Electronic Engineering from Diyala University College of Engineering in 2015. She is now a postgraduate student at Al-Nahrain University, Electronic and Communications engineering department/ M.Sc. student. Her main interest in the electronic and communications field and renewable energy.

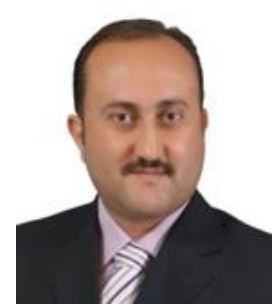

Anas Lateef Mahmood received his B.Sc. in Electronic and Communications Engineering from Al-Nahrain University in 1999. He received his M.Sc. and Ph.D. in Electronic and Communications Engineering / Electronic Circuits and Systems from Al-Nahrain University College of engineering in 2002, and 2007 respectively. He is currently the head of Electronic and Communications Department. His research interest includes power electronics and renewable energy. 